\title{
A Postcolonial Analysis of Entrepreneurship in Africa
}

\begin{abstract}
Global measurement of entrepreneurial activity shows that entrepreneurship in Africa is growing. Similarly, research on African entrepreneurs and their entrepreneurial behaviour appear in an increasing number of scholarly articles. However we note an obvious neglect of a context sensitive approach to both the measurement of entrepreneurial activity and researching entrepreneurship in Africa. In this theoretical paper, we use postcolonial theory, and more specifically Edward Said's idea about the misrepresentation of the Orient by the Occident, to illustrate how existing global measures of entrepreneurial activity fail to provide a real account of entrepreneurship for Africa. We then propose postcolonial theory as a useful analytical tool for researching Africa's case. To justify this proposal, we analyse the region's colonial history, large informal sector, heterogeneous population of entrepreneurs, social entrepreneurship and current geopolitical changes. We then use Homi Bhabha's concept of the 'third space' and Gayatri Chakravorty Spivak's concept of subalternity to critically analyse entrepreneurship research in Africa. To end, we propose a shift towards methodologies which are more context sensitive, recognise the postcolonial setting of Africa and allow agency to emerge during fieldwork.
\end{abstract}

\section{Keywords:}

Africa; entrepreneurship; postcolonial theory; orientalism; third space; subalternity 


\section{INTRODUCTION}

Entrepreneurship is recognised as the engine for economic growth in both developed and developing countries, yet studies focussing on the former populate most of the literature. Africa is the world's second largest continent and it is a place where undertaking business activities, whether for survival or opportunistic reasons, has existed for centuries. Recent statistics indicate improved economic growth, potential for trade and investment (World Bank, 2012). The Doing Business 2013 report identified Africa as striving to make a difference for entrepreneurs and titles 'Africa Rising' (The Economist, 2011) and 'new frontier for business' (The Economist, 2013) makes Africa a heuristically appropriate field for exploring entrepreneurship. In this paper, we would like to look at case of Sub-Saharan Africa (SSA), a region of forty-seven countries (World Bank list) located south of the Sahara desert where research and reports indicate an entrepreneurial revolution (GEM Global report, 2012). However the continuous challenges associated with poverty, corruption, political unrest and unemployment together with failure of Western aid and initiatives has led to an increased belief that it is the African themselves who can pave their way into economic prosperity (Ahmed \& Nwankwo, 2013). Entrepreneurship therefore represents a potential solution to many of the SSA's problems. However research has also widely recognised that poor governance in many SSA countries has hindered entrepreneurial growth (see for example Brautigam \& Knack, 2004; Ntayi et al, 2012; Osman et al, 2011; Sheriff \& Muffatto, 2014). Moreover, poor infrastructure (Godfrey, 2011; Zoogah et al, forthcoming), 
high levels of institutional informality (Rivera-Santos et al, 2014), acute poverty (World Bank, 2011), multi-ethnic group identity (Rivera-Santos et al, 2014) makes business start-ups challenging. Overall these problematic specificities in SSA simultaneously influence opportunities for entrepreneurship to grow and the enterprising individual, both considered necessary for entrepreneurship to develop (Baumol, 1996; Venkataraman et al, 2013).

From a research perspective, most work on entrepreneurship in SSA are driven by theories, frameworks and models derived from Western and developed country contexts for example institutional theory, resource-based theory and transaction cost theory. This overreliance has led to an abundance of research papers ending with prescriptive solutions to foster entrepreneurial growth in a non-Western contexts characterised by historical, political and demographic features as well as relational ambiguities distinct from the West. In the light of this, Kreiser et al (2010) argued for the need to look at the impact of national culture on levels of entrepreneurship both through the cultural values that are part of that society (Hofstede, 1980) and through the institutions that are representative of that culture (Ahlstrom \& Bruton, 2002; Dickson, 2004). In the case of SSA, analysis of entrepreneurship using the nation as a surrogate of culture is rare to the exception of the work of Takyi-Asiedu (1993) who drew on Hofstede's five cultural dimensions to explore the socio-cultural factors retarding entrepreneurship development in Africa. However Bruton et al (2008) noted that national culture in Africa is fragmented with distinct subcultures along ethnic, religious and class basis. From this perspective, few others have given attention to indigenous cultures in the study of entrepreneurship in SSA (see for example the work of Madichie et al (2008) on Nigeria; Urban (2006; 2008) on South Africa and Jenssen \& Kristiansen (2004) on Tanzania). Albeit these 
authors, the use of established theory from developed countries remains the focus of many scholars researching entrepreneurship in SSA while the application of a context relevant lens is still needed.

One leading complex influence on business making in SSA is its colonial legacy or postcolonial context (Ahluwalia, 2001; Jackson, 2012a; Nkomo, 2011; Wood \& Brewster, 2007). Research on entrepreneurship in SSA has given this paramount regional reality limited attention to the exception of a few (see for example Brautigam \& Knack, 2000; Jackson 2012a, 2012b; Rivera-Santos et al, 2014; Storr and Butkevich, 2007). We argue that in order to understand the dynamics of entrepreneurship in SSA, a historically informed theory is crucial and for this a postcolonial lens is required to allow for a more transparent analysis of current entrepreneurial experiences. In support of this, the aim of this paper is to propose postcolonial theory as an analytic tool in understanding the dynamics of entrepreneurship in SSA. Rather than being an attempt to challenge previous theories and models, in this paper it is more about highlighting a theory capable of answering questions in an entrepreneurial context subject to multiple complexities (Shane and Venkataraman, 2001).

Throughout the rest of this paper, we use the term Africa to mean Sub-Saharan Africa. To achieve our aim, we use postcolonial theory to analyse the way entrepreneurship has been measured and researched in Africa. We then deploy concepts from the theory which we believe can aid entrepreneurship research on Africa. To do this, we draw on the dominant informal economy of the region, the entrepreneurs operating in it, the history of the context, the practice of social entrepreneurship and the current geopolitical challenges this context is facing. This paper 
is divided in four parts. Firstly, we describe and discuss postcolonial theory as an analytical tool using the ideas of Edward Said, Homi Bhabha and Gayatri Chakravorty Spivak. In the second part, we use Edward Said's critique of Western ideology and Spivak's concept of subalternity to criticise the way entrepreneurship has been measured in Africa, followed by a discussion of the implications for the representation of informal economy and the consequences these have for the entrepreneurial activities and entrepreneurs in it. In the second part we describe three periods in Africa's history which can help understand how entrepreneurship has evolved in Africa and how colonial values continue to influence Africa's governance and entrepreneurial behaviour. Using indigenisation, we then extend our postcolonial analysis to the practice of social entrepreneurship in Africa and discuss how its conceptualisation in research so far has failed to consider the cultural dynamics and indigenous values that embed perhaps new forms of social entrepreneurship in Africa. In this part, we also apply Bhabha's concept of the 'third space' to discuss how the African entrepreneur is operating in an ambivalent space brought about by its history, colonial legacy and dynamics from globalisation and the presence of China. In the third part, we propose methodological approaches that would suit a postcolonial setting like Africa which also align with the theory proposed. Finally we conclude in the third part by drawing attention to the main contributions and limitations of this paper.

\section{THEORISING THROUGH THE POSTCOLONIAL LENS}

Postcolonial theory is an epistemological perspective which is driven by a critique of colonialism, imperialism and neo-colonialism (Banerjee and Prasad, 2008; Young, 2008; Prasad, 2012). In doing so, it suggests that certain relations are informed by the idea of Europe and are 
marked by boundaries between the supposedly superior and inferior. Its main aim is to critique Eurocentrism and exert constant pressure on and reorient the logics and trajectories of traditional scholarship (Bhabha, 1994; Prasad, 2012). This focus on theorising 'against the grain' (Prasad, 2012) allows it to further understand the geopolitical contexts of societies whose colonial histories continue to influence their present (Jackson, 2012; Kamoche et al, 2012; Gelb et al, 2014; Rivera-Santos et al, 2014; Storr and Butkevich, 2007). Acknowledging that it is difficult to determine a general postcolonial theory (Young, 2008), this paper will use the works of three key postcolonial critics: Edward Said, Homi Bhabha and Gayatri Chakravorty Spivak, which framed the broader aims of the theory as a) to contest the superiority of Western dimensions and the positioning of the non-West as inferior (Said, 1977), b) to give a voice to the colonised 'Other' allowing the subaltern to be heard (Spivak, 1985) and c) to analyse the dynamics of performativity (both human and organisational) in the aftermath of colonialism (Bhabha, 1984). The main ideas of this trinity are discussed in this paper, however for a more detailed understanding of each contributor's work, reading of Said's (1978) Orientalism, Spivak's (1985) Can the Subaltern Speak? and Bhabha's (1994) The Location of Culture is highly recommended.

In Orientalism, Said discusses the hegemony between the Orient (The East) and the Occident (The West or more specifically British and French cultural enter-prises). Described as the cultural leader of the industrialised world, the Occident is seen to have a relationship of power and domination over the Orient. Despite this varying degree of hegemony, Said argues that the Orient has helped define Europe and has become 'an integral part of European 'material' civilization and culture' (Said, 1977: ((2)), emphasis in text). The presence of the West in the aftermath of colonisation is expressed and represented by the persistence of supporting 
institutions, colonial bureaucracies and colonial styles. Said was among the first of postcolonial critics to scrutinize colonialism's discursive practices; he brought to light the rhetorical and representational schemes through which the West constructed and manipulated the representations of the Orient to imperialist ends. One of the recurrent critiques levelled against Said was related to his theorization of colonial discourse. He was faulted for binary thinking and Bhabha was one of the earliest scholars to have criticized Said's assessment of colonial discourse and power.

Whilst acknowledging the pedagogical narrative informed by the idea that the West was morally and intellectually superior, Bhabha however treated people as more than historical events. His focus on performativity views people as contemporaneities who are able to resist the homogenising intent of the pedagogical. Two effects of the performative narrative is that on one hand it leads to the search of new boundaries and invention of new national symbol to maintain hierarchical relations between cultures and on the other hand it subverts the notion of cultural purity. Bhabha used the French word mise en scene to describe the performative temporality as the staging of cultural difference through a set of actions for example political, religious, and commercial and so on. The usefulness of performativity is that it allows the unfolding of narratives from those who are obscured by the nation's pedagogical narrative and gives a voice to minority and obscured groups.

Bhabha used the terms mimicry and hybridity to describe the types of performativity within postcolonial discourse. The former is the process through which the coloniser attempts to force the colonised to act like them so as to make the unfamiliar familiar to facilitate colonial 
domination while simultaneously highlighting the difference in knowledge between the colonised and coloniser. This forces the colonised to import from the coloniser with a desire for a reformed and recognisable Other but where the desire for authenticity becomes a final irony of partial representation only that is "a subject of a difference, that is almost the same, but not quite the same" (Bhabha, 1984:126). The colonised repeats rather than represents and colonial authority has partial presence, both incomplete and virtual. According to Özkazanç-Pan (2008) mimicry produces a space of resistance which destabilises and undermines colonial authority. This space is highly contested, unstable and is always present at the site of colonial dominance (Bhabha, 1994; Ashcroft et al, 1995). In it, positions and feelings of in-betweeness prevail. Bhabha called it the third space. It is accompanied by ambivalence which represents the empowering intentions of the colonizer (Pal \& Dutta, 2008). As Bhabha (1984) pointed out "the discourse of mimicry is constructed around an [ambivalence]: in order to be effective, mimicry must continually produce its slippage, its excess, its difference" (p.126, emphasis in text).

In The Location of Culture Bhabha claimed that cultural production is most productive where there is most ambivalence. This opens the possibility of hybrid spaces able to hold different identities together without entertaining "differences without assumed or imposed hierarchy" (Bhabha, 1994:.4). Bhabha used hybridity to describe a process of cultural assimilation that is never complete (Pal \& Dutta, 2008). For the colonised, hybridity allows them to 'find their voice in a dialectic that does not seek cultural supremacy or sovereignty. They deploy partial culture from which they emerge to construct visions of community, and versions of historic memory, that give narrative form to the minority positions they occupy (Bhabha, 1996). For the coloniser, hybridity is a menace to destabilise the hierarchical relations of power 
and purity (Loomba, 1998). Orientalism and hybridity are often described as two consecutive phases in postcolonial theory or as two competing epistemologies but Fenkel and Shenhav (2006) described them as being complimentary

While Bhabha gave ample consideration to performativity within postcolonial discourse, Spivak focussed on the position of those who were cut off from the lines of social mobility whom she called the subalterns (1985). As a deconstructionist, Spivak strongly criticised the tendency of equivocating the subaltern with the oppressed. For her, the subaltern is not only oppressed but is denied access to communication and democratic systems. While in the case of the oppressed, it is possible to force orthodoxy to recognise their oppression, for the subaltern, there is no recognition that these oppressions are taking place. Marginalisation, domination and subordination weakens if not silences the voice of the subaltern. Like Said, Spivak also used binary opposition of the West (Europe) and the subaltern arguing that it is unreasonable to believe that logic is only held in the hands of the West. Her work, Can the subaltern speak? criticised the way Western cultures investigate other cultures using dominant 'universal' or 'Western-derived' concepts. For this, she used the example of Sati, a Hindu ritual whereby a widowed woman commits suicide by fire by sitting on her husband's funeral pyre. Banning Sati was heard in the voice of the colonisers as the white men saving the brown women from the brown men. This perspective illustrates the West's power to speak for those who cannot, thus hiding the quintessential truth about the act of the subaltern (in this case the widowed women). Today, the term 'subaltern' has come to be associated with specific groups such as peasants, women and people of low social status (Srinivas, 2013) but according to Gramsci, who initially used the term, 'subalternity' can also be an intersectionality of variations of race, class, gender, 
religion and culture (Green, 2011). Arguing that research is colonial, Spivak demanded a rebuild of infrastructure so that agency would emerge and the subaltern is heard. This subject-agent shift becomes fundamental to allow the subaltern to hold logic and create the possibility to metonymise oneself as a part of the whole. Critics of Spivak's initial idea of the subaltern as unable to politically organise and represent itself, pointed to the fact 'no subaltern identity is pure' (Srinivas, 2013, p.1659) and that people shift positions as they develop alliances with the powerful and powerless (Shenhav, 2006), thus making it hard to sometimes separate elites from subalterns (Ludden, 2002).

So where do these postcolonial critics lead us when it comes to entrepreneurial research in Africa? Africa is often described as the permanent colony where the colonial phenomenon is constantly re-processing and re-inscribing itself into new forms. In similar line, several authors have raised the necessary inclusion of a postcolonial lens in research on Africa (see for example Ahluwahlia, 2001; Blunt \& Jones, 1992, 1997; Fenkel \& Shenhav, 2006; Jackson, 2012a; 2012b; 2014; Kamoche et al, 2012; Nkomo,2011 Gelb et al, 2014). However its relevance in understanding the dynamics of entrepreneurship in SSA remains to be adequately discussed. In the following section, we endeavour to do this by applying concepts from the above postcolonial critics an established characteristic of African entrepreneurship: the dominant informal sector, and the space within which Africa's entrepreneurs operate.

\section{DEFINING AND MEASURING ENTREPRENEURSHIP IN AFRICA}

\section{The informal economy}


Entrepreneurship is often described as the solution to Africa's poverty related problems. To empower its people through the right entrepreneurship policies and training has become a necessary inclusion in most papers on entrepreneurship in Africa (see for example Beyene, 2002; Sheriff and Muffatto, 2014). However, it is also known that entrepreneurial activities are nothing new to this continent yet the proclivity of describing this context as lacking a structured entrepreneurship strategy can be justified by the fact that majority of these activities take place within the informal economy of Africa (Amin \& Huang, 2014). The informal sector in Africa has for long been celebrated for its contribution to employment creation and economic growth although activities in this category have often been defined to fall outside of regulated economic activities (Chen,2007) and undertaken by those in the margins of society (Jones, 2010). Some of the common defining features are low set up costs and entry requirements, small scale operations requiring only a few workers, skills usually gained outside formal education and a labour intensive production of goods and services (Becker, 2004). The literature almost too often describes the informal economy as a problem for Africa. Informality resonates with postcolonialism (Woodward and Rolfe, 2011). Informal businesses are not just erratic means of survival but also represent opportunities to generate a sustained livelihood (Naudé, 2010). The pre-conceived fact that only formal businesses account for economic prosperity is well founded in economic theories sustained by the West. Both Said and Spivak critiqued this hegemonic effect of Western definitions of non-Western realities. Universal or Western-derived criteria of formal entrepreneurship including size, registration, tax status, honest accounting, mobility of workplace and access to bank credit have led to more African businesses being represented in the informal economy (Benjamin and Mbaye, 2012). Similarly, using registration status as a 
universal boundary between formal and informal firms, Gelb et al. (2009) found that many micro-enterprises employing less than 5 employees were registered hence making them formal, otherwise informal. This variance is evidence that the way entrepreneurship has been studied in Africa, has been inclined towards what Spivak termed research that is colonial whereby definitions of the 'Other' and the 'Over there' subjects are strongly influenced by Western definitions of formality thus positioning informal entrepreneurship in Africa as inferior. The inability of Africa to rise and contest the superiority of Western dimensions used to describe its current entrepreneurial position remains undiscussed in research and even more using postcolonialism as a theoretical lens.

Entrepreneurial activity in Africa has been measured by The Global Enterprise Monitor (GEM) and the World Bank Entrepreneurship survey (now known as the World Bank 'Ease of Doing Business' index). Both assessment tools have been criticised for lacking connectivity with actual entrepreneurial activity (Ács et al, 2014). The GEM model which uses an Adult Population Survey (APS) and a National Expert Survey (NES) makes the measurement of entrepreneurial performance at national level problematic. The APS which consists of a comprehensive questionnaire written in English is first distributed to over 2000 adults in each country. This is followed by the NES which monitors nine aspects of a country's socio-economic situation including finance, government policies; government programs, entrepreneurial education and training R\&D transfer, commercial and professional infrastructure, internal market openness, physical infrastructure and services and culture and social norms (The GEM model, http://www.gemconsortium.org/Model). The World Bank Enterprise Survey conducts firm-level surveys of a representative sample in the private sector and uses indicators such as finance, 
corruption, infrastructure, crime, competition and performance measures (World Bank Enterprise Survey, 2014). Overall, both GEM and the World Bank Entrepreneurship Survey measure entrepreneurship based on three categories: output, attitude and framework indicators. The focus on a standardised approach only accounting for a) emergence or registration of new firms, b) willingness to undertake entrepreneurial activity and c) existence of regulations and institutional conditions conducive to entrepreneurial activity, have clearly omitted agency (the entrepreneur) as a necessary component of entrepreneurship. Greater emphasis on a country's socio-economic milieu, wider inclusion of country business and political experts, registered business owners and top managers, all evidence a distorted picture of entrepreneurship in Africa. Both tools are typical examples of Western hegemony around simultaneously defining and measuring entrepreneurial activity for a context where the story on entrepreneurship is different. Their procedures for investigation and research although operating as a procedure of knowledge, have been operating as techniques of power.

\section{A case of subalternity}

The overlooking of informal entrepreneurial activities and the underrepresentation of its people lead to a case of both having positions without identity (Spivak, 1985) in the current world scene. This exclusion from communication channels (GEM reports and 'Ease of doing business' reports are extensively used to communicate with policy-makers both nationally and globally) limits the informal entrepreneur's possibility of becoming part of the whole and to release the possibility of creating possibilities for itself. In other words, the informal entrepreneur 
is made a subaltern on a national and international scale by the way entrepreneurship is measured: it is not represented and is marginalised. However, the question to ask is should African informal entrepreneurs be silenced in global initiatives to measure entrepreneurship? The heterogeneity of this group perhaps answers this. The proclivity to label the informal economy in Africa as the economy of the poor is strongly related to the connection made between informal entrepreneurial activities and the survivalist nature of its constituents. However generalisation would be a major mistake. Fields (1990) was the initial scholar who counter argued the above stating that there is also an 'upper-tier informal sector' comprising of micro-enterprises with a higher degree of capitalisation, as well as better educated and skilled workers. Unlike others in the sector, these micro-enterprises have been described as pro-cyclical following similar growth patterns as the overall economy. Alongside increasing numbers of micro-enterprises demonstrating diverging features from the traditional informal operator, research has also shown that there is a significant number of large informal businesses who share commonalities with their counter formal operators but remain part of the informal sector (see for example: Benjamin and Mbaye, 2012). There is evidence that in some African countries such as Senegal and other Western African contexts, some large informal firms are dominating sectors such as importexport trading, domestic wholesale-retail, transportation and construction. Furthermore, Grimm et al (2012) categorised informal entrepreneurs in West Africa as top performers, 'constrained gazelles' and survivalists. The difference between the last two is that unlike the survivalist who faces both external (access to capital, insurance and infrastructure) and individual (education, finance and generic business skills) constraints, the 'constrained gazelles' are mainly constrained by their business environment. They are educated and possess business skills and understand 
market conditions. If access to a supportive business environment is possible, they can equally join the top-performers. Progression from survivalist to the upper echelon is possible.

Spivak's concept of subalternity can be beneficial in understanding the dynamics of informal entrepreneurship in Africa given the complex heterogeneity of its constituents by gender, ethnicity, class as well as sector. As put forward by Srinivas, the subaltern has come to be associated with peasantry, women, people of low status, people of certain ethnicities and race as well as class (although class is not necessarily a marker of subalternity). Furthermore, intersectionality between these variations can produce deeper instances of subalternity. In the case of the informal sector in Africa there is ample evidence that these characteristics exist hence rationalising theorising entrepreneurship in a way that will represent the voices of these people. However labelling individuals as subalterns within the informal economy should not be solely based on their gender, ethnicity or class as not all women are subalterns, not all black entrepreneurs are subalterns and not every poor person is a subaltern. The shifting of positions of the subaltern should not be overlooked as there are many cases in Africa where the subaltern has risen (see for example Lindell, 2010). By theorising differently, we should not try and protect them and speak on their behalf, instead we should create the spaces from which they can speak for themselves (Spivak, 1985) and this can have methodological implications which will be discussed later in the paper.

The above is a typical example of how global measurement tools like GEM and the World Bank Entreprise Survey have ultimately silenced those who are making an essential contribution to the economic development of Africa thus making them absent from the 
discussions on strategic ways to improve their conditions. Ideology-control is a major problem for Africa as discourse on what constitutes entrepreneurship (both theory and research) is legitimised by the West (Ogbor, 2000). The misconception of African entrepreneurship is reflected in a history of efforts by entrepreneurial researchers to explain 'who' is an entrepreneur and 'what' constitutes entrepreneurship in Africa as a response to existing research which treat the participation of non-dominant groups as dysfunctional to theory development. (Baker et al., 1997; Jackson and Konz, 1998; Nkomo, 1992). Postcolonial theory therefore questions research which adopts the assimilation mentality where the tendency of researchers to focus on questions of 'why aren't they like us, or how can they become like us?' (Nkomo, 1992, p. 496).

\section{ENTERPRISING IN THE 'THIRD SPACE'}

\section{History matters}

Along with being the victim of ideology-control, Africa's economy is situated in dense cross-cultural intersections. Entrepreneurs, be they formal or informal are operating in a dynamic space whereby past colonial dominance continues to influence the cartographies of business and neo-colonialist ventures from the North (Europe), West (America), and East (China) are challenging the status quo. To further understand this, a closer analysis of the entrepreneurial space in Africa is required. In the first instance, Africa's colonial history has had consequential impact on the way both entrepreneurship has developed and the way it has been labelled and managed. Therefore it is necessary to understand its history first in order to understand Africa's institutions, constraints, poor performances and divergent patterns of development. However as it 
is beyond the scope of this paper to produce a detailed account of this region's colonial history, we will only highlight some historical facts relevant to this paper.

Business historians account for three pertinent periods in Africa's history: pre-colonial, colonial and post-colonial. Evidence suggests that indigenous entrepreneurial activities and complex commercial organisations existed before colonisation. Despite these forms of commercial capitalism, no indigenous bourgeoisie emerged due to constraints existing prior to the arrival of the imperials (Hopkins, 1987). The colonial period then marked the entry of expatriate enterprises in Africa. These firms operated in areas of export production including mining and agriculture, trade, and services including shipping and banking. They also put pressure on colonial governments by demanding better conditions and incentives for investment in the region while simultaneously competing with both the government and existing indigenous businesses. The absolute objective of the colonial state was to maintain high control of the economy and to sustain this as well as the interests of expatriate firms. It made Africans available for wage labour by keeping them away from becoming independent producers (Ake, 2001). This arbitrary power was symbolic of the colonial state's domination disguised under a civilising mission. Post-colonisation and after independence, the character of the state remained totalistic. Ake described independence as the handover of government to their African successors who could be trusted with their values. Albeit this, the post-colonial era was marked by the emergence of transnational corporations, state agencies and indigenous firms.

\section{Indigenisation}


Independent African governments called for policies to restore the sovereignty of Africans through policies of indigenisation and economic indigenisation. However, due to the ethnic and racial divisions, indigenisation may have deepened inequalities in some states (see for example the case of Zambia in Beveridge, 1974). From the above, it is evident that indigenous entrepreneurship which refers to entrepreneurial activities undertaken by black Africans was never in the colonisers agenda for economic growth. Their arbitrary positions had resulted in the indigenous population being used mainly as a source of wage labour than a commercial capitalist per se. To date, despite an acknowledgement that entrepreneurship is the solution to Africa's socio-economic problems and evidence that it has and continues to contribute to employment and economic growth, a reductionist perception of Africans as entrepreneurs remains. The practices relating to African entrepreneurial activity continue to be misread by those whose research is colonial. A closer look is required into cultural and historical dynamics in Africa and postcolonial theory allows for this rethinking. The African entrepreneur is operating in a context where colonial values remain embedded in many institutional practices. Could this be the rationale behind a) African states unwilling to create a supportive business environment for entrepreneurship to flourish, b) lack of recognition and degradation of the informal entrepreneurial activities and c) lack of trust in the authorities by both formal and informal entrepreneurs? Bhabha stated that the space of colonial dominance is ambivalent whereby different identities can be sustained. Africans and their institutions are ambivalent by virtue of their colonial history and the legacies of the colonial systems which continue to influence politics, business and society. This has created a third space which is consequential for our understanding of entrepreneurship in Africa. By opening the possibility of hybridity, the third 
space is useful in understanding institutional complexities and informality, as well as the way entrepreneurship in undertaken. In the latter, hybridity is not simply adding here to there, but rather it is embedded in power and serves to understand and identify non-traditional forms resistance. In this case, the emergence of an informal sector where entrepreneurial activities coexist and compete with formal businesses may represent a form of resistance against lack of institutional support. Moreover, the acceptance and continued existence of an informal economy in Africa may be interpreted as a way through which the subaltern is trying to find its voice without seeking cultural supremacy or sovereignty but simple autonomy (Loomba, 1998). Similarly, indigenisation is in itself resistance against continued domination post-colonisation. Its call for restoring African values such as Ubuntu (South Africa) and Chimvrenga (Zimbabwe), Nnewi (Anambra State, Nigeria) in business is a necessary inclusion in African entrepreneurship research. Mangaliso's (2001) work on 'Building Competitive Advantage from Ubuntu: Management Lessons from South' is a good example of how indigenous values bear significant importance for business. Unfortunately, much of the gaze on informality in Africa has been suspicious and this calls for a much needed attention to cultural dynamics and indigenous value systems surrounding how informality is defined and applied to entrepreneurship.

\section{Social entrepreneurship}

Social entrepreneurship in Africa has been researched without much application of contextual cultural dynamics. Ideology-control mechanisms have led to a dearth of research on the actual way these enterprises operate and how values and cultural norms are being embedded in them. By definition, social entrepreneurship is the generation of business activities for social 
benefit (see Visser (2011: 235) for a table summarising the typical definitions of the social entrepreneur and social entrepreneurship). The term is used to refer to the rapidly growing number of organizations that have created models for efficiently catering to basic human needs that existing markets and institutions have failed to satisfy. Social entrepreneurship combines the resourcefulness of traditional entrepreneurship with a mission to change society (Seelos and Mair, 2007). In itself, the term is a hybrid between business principles and methods applied not for individual gain and profit, but for group or social gain and for social change (Dees, 2001; Mort and Weerawardena, 2007). In Africa, the extent of social entrepreneurship varies across states due to different degrees of success in attracting foreign aid (Visser, 2011). Thus, the concept itself has come to be associated with aid, micro-financing and non-governmental organisations (NGOs). The ultimate goal is the creation of a social enterprise by a social entrepreneur who will add social value to help improve the life of the underprivileged. The success rate of these enterprises across Africa is yet to be determined given the concentration of social entrepreneurship research a few Africa countries only.

To date, research done on social entrepreneurship in Africa lacks adequate consideration to socially-embedded values and norms existing in the country where it is operating. Katzenstein and Chrispin (2011: 88) pointed out that 'when operating in developing countries, issues of government intervention, cultural biases, colonial traditions and processes used by the development community all impact the methods by which social entrepreneurs successfully function'. Ubuntu was mentioned in the work of Urban $(2006 ; 2008)$ but without further application. A relevant entrepreneurial framework was presented in the work of Imas, Wilson and Weston (2012) giving a voice to the 'barefoot entrepreneur'. Researchers acknowledging 
informal financing in African social entrepreneurship literature are rare despite previous research confirming its relevance to the context (see for example Miracle et al, 1980; Buckley, 1997; Fafchamps, 2004). Overall social entrepreneurship research in Africa remains dominated by Western-derived definitions and ideologies about it. The main discourse of social entrepreneurship is the empowerment of the poor (Daya, 2014) and the missions, businesses and results of its activities stem from interaction which social entrepreneurs maintain with members of that society (Karanda and Toledano, 2012). Therefore, consideration of contextual influences is fundamental as African social entrepreneurship may lay ground for hybrid enterprises displaying both characteristics of Western social enterprises as well as African value systems.

\section{An ambivalent space}

Overall, the entrepreneurial space in Africa is complex. It faces enormous pressure from the growing need to indigenise, competition from Western organisations and the presence of China in Africa. It is undisputable that the waves of globalisation have changed much of the consumption patterns of Africans. Demand for global capital goods is on the increase and presents major opportunities for entrepreneurship to grow. At the same time, the strengthening of relations between the China and Africa also has led to an influx of Chinese small enterprises and a proliferation of Chinese products on the local stage (Lin, 2014). These major global economic shifts are likely to impact on the way entrepreneurship is enacted and performed. A closer look is therefore needed at the staging of cultural difference within such complex intersections. Postcolonial theory and in particular Bhabha's concept of a 'third space' can highlight various manifestations of mimicry and hybridity operating within the African entrepreneurial space. It 
can help the research see how entrepreneurship in Africa is continuously reformulated by the interactions with its local culture and that of the foreigner. Ambivalence is always present at the place of colonial dominance but little is known about how the African entrepreneur negotiates with this.

\section{MOVING FORWARD: METHODOLOGICAL IMPLICATIONS}

The impact of ideology control on entrepreneurial theorizing in Africa is reinforced by a pervasive influence of ideology on the methods of inquiry used in researching the field. An obvious dehumanisation of the research context can be witnessed together with an overuse of quantitative methods embedded in a positivist epistemology which according to Schumpeter is inadequate in understanding the entrepreneurial phenomenon. Similarly, Gartner (1993, p. 236), pointed out that: 'there is no average in entrepreneurship. It seems a contradiction to talk about "average entrepreneurs", that is, to lump a bunch of people together who seem to be involved in the processes that generate wide variation in their organization formation experiences and then compare the "average" of their experiences to the "average" of some other group of individuals". Research in postcolonial settings must be informed by resistance to Euro-Western throughts. Thus, interpretivist and critical postcolonial philosophies which adopt a 'critical interpretivist' perspective (Alvesson and Deetz, 2000; Jack and Westwood, 2006) that incorporates a critical postcolonial lens becomes favourable for researching these contexts. This perspective involves critically problematising (Alvesson and Sandberg, 2011) current knowledge to ascertain how non-Western perspectives are currently accounted for in knowledge and, following this, gaining insight into social phenomena (Saunders et al, 2009) in a manner which accounts for local nonWestern perspectives (Frenkel and Shenhav, 2006; Westwood, 2001). 
Chilisa (2011) warns about the disturbing role of Anglo-European theory in framing research objectives in postcolonial settings. In this light, it therefore becomes the job of the researcher to avoid the use of ideology-controlled theory in the field of entrepreneurship research in Africa. Furthermore, the researcher's aim should be a) to create a space where participants (colonised) can reclaim their culture (Chilisa, 2011), b) give a 'voice' to the colonised Other (Muecke, 1992:10) and c) use the gaze of the colonised to create new research methodologies (Chilisa, 2011). At the onset, it is easier to look for Western-defined forms of entrepreneurship but Tsui (2004) calls for emphasising non-Western forms of engagement which we believe is lacking in current research. Therefore the role of the researcher is to remove the ethical problems which Spivak associated with studying a different culture using 'universal' or 'Western'-derived concepts and frameworks. Definitions and interpretations should be based on the words and eyes of the colonised Other. Hence those methods that are able to capture the day to day encounters of starting and managing either a profit-making or non-profit-making activity should be sought. The aim should be the search of agency in the colonised Other's world using those methodologies which allow close encounters for example ethnography which is participant-centred, and appropriate for gaining insights about contexts and understanding them from the multi-vocal (many voices) perspective of those involved (Ybema et al., 2009). This is achieved by focusing directly on the way in which people undertake certain actions in a particular context, and by understanding it from their perspective and allows the researcher to gain an understanding of people's interpretations from direct participation in their world (Obbo, 2006). To achieve this, a researcher will typically become immersed in the social world and extensively observe participants' behaviour. This allows for a deeper understanding of performativity in the context 
of the entrepreneur and a more prolonged exposure to the staging of cultural difference. This will concomitantly allow the unfolding of narratives and allow the subaltern to participate in global construction of meanings. We believe that the search for the quintesessential truth lies firstly in the narratives of the entrepreneur, subaltern or not and secondly in the entrepreneur's performativity. Narratives account for human experience and is based on experience expressed in lived and told through stories (Pinnegar and Daynes, 2007). A particular advantage of this approach is that it reflects the way people naturally communicate (Benham, 2007; Czarniawska, 2004). As well as this, it is able to vividly reflect the perspective and voice of the narrator or characters in the story (Leavy, 2009), thus making the perspective of the individual prominent, and also at the same time bring theories to life (Phillips, 1995). Visser's (2011) work and Imas, Wilson and Weston's (2012) work both give a vivid example of narratives via stories in their research.

\section{CONCLUSIONS}

In this paper we have proposed postcolonial theory as an analytical tool relevant for researching entrepreneurship in Africa. By drawing on the work of Said, Spivak and Bhabha, we have discussed how current studies have overlooked the history, the heterogeneous characteristics and cultural dynamics of Africa. Our aim was not to undermine the value of existing research done using Western-derived theories and frameworks but more to highlight what they have been unable to define and explain. Our emphasis on the use of methodological approaches that are more humanistic and culturally informed therefore questions current representations of African entrepreneurship on the world scene. Though we have discussed the 
appropriateness of ethnography and narratives as research methods appropriate to the postcolonial setting of Africa, it should be the aim of future research to identify new methodologies which allow African entrepreneurs to define their reality and ways of knowing. The main contribution of this paper is that it has identified that the way entrepreneurship is researched in Africa restricts avenues for understanding the reality of how entrepreneurial activities are conducted. It provide grounds for a redefinition of the concept in context and lends a closer ear to those who are making valid contributions to economic growth in Africa. The theory put forward is rare in entrepreneurship research but embracing it can enhance much of our understanding of postcolonial contexts. The main limitation of this research that it is based on a theoretical analysis of the problem. Therefore future research should aim at conducting fieldwork to illustrate the usefulness of the theory.

\section{REFERENCES}

Ács, Z. J., Autio, E., \& Szerb, L. 2014. National Systems of Entrepreneurship: Measurement issues and policy implications. Research Policy, 433: 476-494.

Ahlstrom, D; \& Bruton, G.D. 2002. An institutional perspective on the role of culture in shaping strategic actions by technology-focused entrepreneurial firms in China. Entrepreneurship Theory and Practice, 26: 53-69.

Ahluwalia, P. 2001. Politics and Post-colonial Theory: African Inflections. London: Routledge 
Ahmed, A., \& Nwankwo, S. 2013. Entrepreneurship development in Africa: an overview. World Journal of Entrepreneurship, Management and Sustainable Development, 9: 82-86.

Ake, C. 2001. Democracy and development in Africa: Brookings Institution Press.

Alvesson, M; \& Deetz, S. 2000. Doing Critical Management Research. London: Sage.

Alvesson, M; \& Sandberg, J. 2011. Generating research questions through problematization. Academy of Management Review, 36: 247-271.

Amin, M; \& Huang, W. 2014. Does firm size matter in the informal sector? World Bank Enterprise Survey available at http://www.enterprisesurveys.org/ /media/GIAWB/EnterpriseSurveys/Documents/Enterpri $\underline{\text { seNotes/Does-Firm-size-Matter-in-Informal-Sector.pdf }}$

Ashcroft, B; Griffiths, G; \& Tiffin, H. (Eds). 1995. The post-colonial studies reader. London: Routledge

Baker, T., Aldrich, H. E; \& Liou, N. 1997. The invisible entrepreneurs: the neglect of women business owners by mass media and scholarly journals in the USA. Entrepreneurship and Regional Development, 9: 221-38.

Banerjee, S. B. \& Prasad, A. 2008. Introduction to the special issue on "Critical reflections on management and organizations: a postcolonial perspective. Critical Perspectives on International Business, 4: 90-98.

Baumol, W. J. 1996. Entrepreneurship: Productive, unproductive, and destructive. Journal of business venturing, 11: 3-22. 
Benham, M. K. P. 2007. 'Mo'ōlelo'. In D.J. Clandinin, (Ed) Handbook of Narrative Enquiry: Mapping a Methodology: 512-533. Thousand Oaks: Sage.

Benjamin, N; \& Mbaye, A. A. 2012. The Informal Sector in Francophone Africa: Firm Size, Productivity, and Institutions. World Bank-free PDF.

Beveridge, A. A. 1974. Economic independence, indigenization, and the African businessman: Some effects of Zambia's economic reforms. African Studies Review, 17: 477-490.

Beyene, A, 2002. Enhancing the competitiveness and productivity of small and medium scale entreprises (SMEs) in Africa: An analysis of differential roles of national governments through improved support services. Africa Development, 27:130-56

Bhabha, H. 1984. Of mimicry and man: the ambivalence of colonial discourse. October 28: 125133.

Bhabha, H. 1994. The location of culture. Routledge: London.

Bhabha, H.1996. Culture's in-between. In S. Hall; \& P. du Gay (Eds) Questions of cultural identity: 53-60. London: Sage.

Bräutigam, D. A., \& Knack, S. 2004. Foreign Aid, Institutions, and Governance in Sub-Saharan Africa*. Economic development and cultural change, 52: 255-285.

Bruton, G. D., Ahlstrom, D., \& Obloj, K. 2008. Entrepreneurship in Emerging Economies: Where Are We Today and Where Should the Research Go in the Future. Entrepreneurship Theory and Practice, 32: 1-14. 
Buckley, G. 1997. Microfinance in Africa: Is it either the problem or the solution? World Development, 25:1081-1093.

Chen, M. A. 2007. Rethinking the Informal Economy: Linkages with the Formal Economy and the Formal Regulatory Environment. DESA Working Paper no. 46. New York: United Nations Department of Economic and Social Affairs.

Chilisa, B. 2011. Indigenous research methodologies: SAGE Publications.

Czarniawska, B. 2004. Narratives in Social Science Research. London: Sage.

Daya, S. 2014. Saving the Other: Exploring the social in social enterprise. Geoforum, 57: 120128.

Dees, J.G. 2008. Philanthropy and Enterprise: Harnessing the Power of Business and Social Entrepreneurship for Development. Innovations, 3: 119-132.

Dickson, P. 2004. Entrepreneurial orientation: The role of institutional environment and firm attributes in shaping innovation and proactiveness. Paper presented at the Strategic Management Society Conference, San Juan, Puerto Rico.

Fafchamps, M. 2001. Networks, Communities and Markets in Sub-Saharan Africa: Implications for Firm Growth and Investment. Journal of African Economies, 10: 109-142.

Fields, G. S. 1990. Labour Market Modeling and the Urban Informal Sector: Theory 
and Evidence. In D. Turnham; B. Salomé; \& A.Schwarz. (Eds.) The Informal Sector Revisited. Paris: Development Centre of the Organisation for Economic Co-Operation and Development.

Frenkel, M. and Shenhav, Y. 2006. From binarism back to hybridity: a postcolonial reading of management and organization studies', Organization Studies, 27: 885-876

Gelb, A., Meyer, C. J., \& Ramachandran, V. 2014. Development as diffusion: Manufacturing productivity and sub-Saharan Africa's missing middle: WIDER Working Paper.

Gartener, W. B. 1993. Words lead to deeds: towards an organizational emergence vocabulary. Journal of Business Venturing, 8: 231-9.

Gelb, A., Mengistae, T., Ramachandran, V., \& Shah, M. K. 2009. To Formalize or not to formalize? Comparisons of microenterprise data from Southern and East Africa. Centre for Global Development working paper, 175.

GEM (Global Enterprise Monitor) Global report, 2012 available at http://www.gemconsortium.org/docs/2645/gem-2012-global-report

Godfrey, P. C. 2011. Toward a theory of the informal economy. Academy of Management Annals, 5: 231-277

Green, M. 2011. Rethinking the Subaltern and the question of censorship in Gramsci's Prison Notebooks. Postcolonial Studies, 14:387-404 
Grimm, M., Knorringa, P., \& Lay, J. 2012. Constrained Gazelles: High Potentials in West Africa's Informal Economy. World Development, 40: 1352-1368.

Hofstede, G. 1980. Culture's consequences: International differences in work-related values. Newbury Park, CA: Sage Publications.

Hopkins, A. G. 1987. Big Business in African Studies. The Journal of African History, 28: 119140.

Imas, J.M., Wilson, N., \& Weston, A. 2012. Barefoot Entrepreneurs. Organization, 19: 563-585.

Jack, G; \& Westwood, R. 2006. Postcolonialism and the politics of qualitative research in international business. Management International Review, 46: 481-501.

Jackson, J; \& Konz, G. (1998). Black women entrepreneurs. In, J. Biberman; \& A. Alkhafaji (Eds.). Business Research Yearbook 5: 536-9.

Jackson, T. 2012a. Postcolonialism and organisational knowledge in the wake of China's presence in Africa: Interrogating south-south relations. Organisation, 19:181-204

Jackson, T. 2012b. Cross-cultural management and the informal economy in sub-Saharan Africa: implications for organization, employment and skills development. The International Journal of Human Resource Management, 23: 2901-2916.

Jackson, T. 2014. How can we encourage indigenous research? International Journal of Cross Cultural Management, 14: 135-137. 
Jenssen, J. I., \& Kristiansen, S. 2004. Sub-cultures and entrepreneurship: the value of social capital in Tanzanian business. Journal of Entrepreneurship, 13: 1-27.

Jones, J. L. 2010. Nothing is Straight in Zimbabwe: The Rise of the Kukiya-kiya Economy 2000-2008. Journal of Southern African Studies, 36: 285-299.

Kamoche, K., Chizema, A., Mellahi, K.,\& Newenham-Kahindi, A. 2012. New directions in the management of human resources in Africa. The International Journal of Human Resource Management, 23: 2825-2834.

Karanda, C; \& Toledano, N. 2012 Social entrepreneurship in South Africa: A different narrative for a different context, Social Enterprise Journal, 8: 201 - 215.

Katzenstein, J., \& Chrispin, B. R. 2011. Social entrepreneurship and a new model for international development in the 21st century. Journal of Developmental Entrepreneurship, 16: $87-102$.

Kreiser, P. M., Marino, L. D., Dickson, P., \& Weaver, K. M. 2010. Cultural influences on entrepreneurial orientation: The impact of national culture on risk taking and proactiveness in SMEs. Entrepreneurship Theory and Practice, 34: 959-983.

Leavy, P. 2009. Method Meets Art: Arts-Based Research Practice. New York: Guilford Press.

Lin, E. 2014. Big Fish in a Small Pond: Chinese Migrant Shopkeepers in South Africa. International Migration Review, 48: 181-215.

Lindell, I. 2010. Informality and collective organising: identities, alliances and transnational activism in Africa. Third World Quarterly, 31: 207-222. 
Loomba, A. 1998. Colonialism/postcolonialism. London: Routledge.

Ludden, D. 2002. A Brief History of Subalternity. In D. Ludden. (Ed.). Reading Subaltern Studies: Critical History, Contested meanings and the Globalisation of South Asia:139. London: Anthem.

Madichie, N. O., Nkamnebe, A. D., \& Idemobi, E. I. 2008. Cultural determinants of entrepreneurial emergence in a typical sub-Sahara African context. Journal of Enterprising Communities: People and Places in the Global Economy, 2: 285-299.

Mangaliso, M. P. 2001 Building competitive advantage from Ubuntu: management lessons from South Africa. Academy of Management Executive, 15:23-33

Miracle, M. P., Miracle, D. S., \& Cohen, L. 1980. Informal savings mobilization in Africa. Economic development and cultural change, 701-724.

Mort, G; \& Weerawardena, J. 2007. Social Entrepreneurship. In A. Sargeant; \& W. Wymer Jr. (Eds.). The Routledge Companion to Nonprofit Marketing: 220-236: Routledge.

Muecke, S. 1992. Textual Spaces: Aboriginality \& Cultural Studies. Sydney: New South Wales University Press

Naudé, W. 2010. Promoting Entrepreneurship in Developing Countries. Policy Challenges. United Nations University, 4.

Nkomo, S. M. 1992. The emperor has no clothes: rewriting "race in organizations". Academy of Management Review, 17: 489-513. 
Nkomo, S.M. 2011. A Post-colonial and Anti-Colonial Reading of 'Africa' Leadership and Management in Organization Studies: Tensions, Contradictions and Possibilities. Organization, 18: 365-386

Ntayi, J. M., Mutebi, H., Kamanyi, S., \& Byangwa, K. 2013. Institutional framing for entrepreneurship in sub-Saharan Africa: a case of Uganda. World Journal of Entrepreneurship, Management and Sustainable Development, 9: 133-154.

Obbo, C. 2006. But we know it all! African perspectives on anthropological knowledge. In M.Ntarangwi; D. Mills: \& M, Babiker. (Eds.) African Anthropologies: History, Critique and Practice: 154-169. London: Zedd Books.

Ogbor, J. O. 2000. Mythicizing and Reification in Entrepreneurial Discourse: Ideology-Critique of Entrepreneurial Studies. Journal of Management Studies, 37: 605-635.

Osman, R. H., Alexiou, C., \& Tsaliki, P. 2011. The role of institutions in economic development: Evidence from 27 Sub-Saharan African countries. International Journal of Social Economics, 39: 142-160.

Özkazanç-Pan, B. 2008. International management research meets "the rest of the world". Academy of Management Review, 33: 964-974.

Pal, M; \& Dutta, M. 2008. Theorising resistance in a global context. In C. Beck. (Ed.) Communication Yearbook: 41-87. New York: Routledge.

Phillips, N. 1995. Telling organizational tales: On the role of narrative fiction in the study of organizations, Organization Studies, 16: 625-649. 
Pinnegar, S. \& Daynes, J. G. 2007. Locating narrative inquiry historically: Thematics in the turn to narrative. In D.J. Clandinin. (Ed.). Handbook of Narrative Inquiry: Mapping a Methodology: 3-34. Thousand Oaks: Sage.

Prasad, A. 2012. (Ed). Against the grain: advances in postcolonial organization studies. copenhagen Business School Press DK

Rivera-Santos, M., Holt, D., Littlewood, D., \& Kolk, A. 2014. Social entrepreneurship in subSaharan Africa. The Academy of Management Perspectives, amp. 2013.0128.

Said, E. (1977). Orientalism. New York: Vintage Books available at http://www.odsg.org/Said_Edward(1977)_Orientalism.pdf

Saunders, M., Lewis, P; \& Thornhill, A. 2009. Research Methods for Business Students. 5th ed. Harlow: Pearson Education Limited.

Seelos, C., \& Mair, J. 2007. Profitable business models and market creation in the context of deep poverty: a strategic view. The Academy of Management Perspectives, 21: 49-63.

Shane, S., \& Venkataraman, S. 2001. Entrepreneurship as a Field of Research: A Response to Zahra and Dess, Singh, and Erikson. Academy of Management Review, 26: 13-16.

Shenhav, Y. 2006. The Arab Jews: a Postcolonial Reading of Nationalism, Religion, and Ethnicity. Stanford, CA: Stanford University Press.

Sheriff, M., \& Muffatto, M. 2014. Reviewing Existing Policies For Unleashing And Fostering Entrepreneurship In Selected African Countries. Journal of Developmental Entrepreneurship, 19: 1450016/1-1450016/36 
Spivak, G.C. 1985. Can the Subaltern Speak? Speculations on Widow-Sacrifice.

Wedge, Winter/Spring: 120-30.

Srinivas, N. 2013. Could a Subaltern Manage? Identity Work and Habitus in a Colonial Workplace. Organisation Studies, 34: 1655-1674

Storr, V. H., \& Butkevich, B. 2007. Subalternity and entrepreneurship: Tales of marginalized but enterprising characters, oppressive settings and haunting plots. The International Journal of Entrepreneurship and Innovation, 8: 251-260

Takyi-Asiedu, S. 1993. Some socio-cultural factors retarding entrepreneurial activity in subSaharan Africa. Journal of business venturing, 8: 91-98.

The Economist. 2011. Africa rising. December 3, 2011.

The Economist. 2013. Investing in Africa - The hottest frontier. The Economist, Apr 6.

The GEM model available at http://www.gemconsortium.org/Model

Tsui, A. 2004. Contributing to global management knowledge: A case for high quality indigenous research. Asia Pacific Journal of Management, 21: 491-513.

Urban, B. 2008. Social entrepreneurship in South Africa, International Journal of Entrepreneurial Behaviour \& Research, 14: 346 - 364.

Urban, B. 2006. Entrepreneurship in the rainbow nation: Effect of cultural values and ESE on intentions. Journal of Developmental Entrepreneurship, 11: 171-186. 
Venkataraman, S., Sarasvathy, S. D., Dew, N., \& Forster, W. R. 2013. Of narratives and artifacts. Academy of Management Review, 38: 163-166.

Visser, K. 2011. Social entrepreneurship in South Africa: context, relevance and extent. Industry and Higher Education, 25: 233-247.

Westwood, R. 2001. Appropriating the other in the discourses of comparative management. In S. Linstead; \& R. Westwood. (Eds.) The Language of Organization: 241-282. London: Sage.

Woodward, D., Rolfe, R., Ligthelm, A., \& Guimaraes, P. 2011. The viability of informal microenterprise in South Africa. Journal of Developmental Entrepreneurship, 16: 65-86.

Wood, G., \& Brewster, C. 2007. Introduction: Comprehending industrial relations in Africa. In G. Wood and C. Brewster (Eds.), Industrial relations in Africa: 1-14. London: Palgrave.

World Bank, 2012. Ease of Doing Business Survey. Washington DC.

World Bank Enterprise Survey, 2014 available at http://www.enterprisesurveys.org/methodology

Ybema, S., Yanow, D., Wels, H. \& Kamsteeg, F. 2009. Studying everyday organizational life In S. Ybema, S (Ed.) Organizational Ethnography: Studying the Complexities of Everyday Life: 1-20. London: Sage.

Young, R. J. C. 2008. Postcolonialism: An historical introduction. Oxford: Blackwell

Zoogah, D. B., Peng, M. W., \& Woldu, H. Institutions, resources, and organizational effectiveness in Africa. Academy of Management Perspectives. Forthcoming 2014. 
(15199) 